\title{
OHTSUKI KENJI AND THE BEGINNINGS OF LAY ANALYSIS IN JAPAN
}

\author{
GEOFFREY BLOWER AND SERENA YANG HSUEH CHI, HONG KONG
}

\begin{abstract}
The authors outline the major role played by Ohtsuki Kenji in the formation of the Japanese Psychoanalytic Society. Unlike the other pioneers of psychoanalysis in Japan, Ohtsuki never went abroad or met Freud. He was a literature graduate who taught himself the fundamentals of psychoanalysis. He organised the translation of Freud's complete works, formed a psychoanalytic training institute and started a journal that carried English-language editorials. These became the major means whereby foreign analysts came to know and understand the Japanese psychoanalytic scene. A number of rival groups amalgamated to form the Japanese Psychoanalytical Association in the mid-fifties, excluding Ohtsuki's group despite its pre-war prominence. The authors reconsider Ohtsuki's role in the light of his many articles, his autobiography, new information uncovered in interviews conducted with current analysts and with Ohtsuki's widow and son. They describe his championing of lay analysis, and his criticisms of medicalisation of the discipline and of the view from abroad that questioned the suitability of Japanese culture for psychoanalytic therapy, as well as his efforts to modify some of the basic tenets of psychoanalysis to accord with his own views in his later work.
\end{abstract}

Although papers advocating Freud's early ideas began appearing in Japan from 1912 onwards, the tasks of disseminating his theories through university lectures, setting up institutes, starting journals, supervising translations of his works and training a new generation of analysts came to rest with four men (Blowers \& Yang, 1997). Between 1930 and 1933 three of them went abroad, met Freud and were briefly analysed by his associates. Two were medical doctors, the third a psychologist. As each returned, their career paths diverged. Marui Kiyoyasu, ${ }^{1}$ a psychiatrist from Sendai, had been the first to teach psychoanalysis in a University (Tohoku). He continued doing so after his trip to Europe. His student, Kosawa Heisaku, returned from his spell in Vienna to open a private practice. Yabe Yaekichi, the psychologist, who worked for Japan's Railway Ministry, had opened an institute for psychoanalysis, where people could gather to discuss Freudian matters. He continued to promote this as a training centre for lay analysts.

The fourth man, Ohtsuki Kenji, who was neither a doctor nor a specialist in an allied discipline, did not travel to Vienna, nor anywhere else abroad. Although he was a literature graduate, he attended no lectures on psychoanalysis. By his own account he was a self-taught independent scholar (Ohtsuki, 1951). Yet he came to occupy a central place in the development of psychoanalysis in Japan, although this has never been officially recognised. He supervised the translation of a complete set of Freud's works, founded the first Japanese psychoanalytic journal, published his own translations of many articles written by analysts abroad, ran a psychoanalytic institute and clinic out of his own house, and vigorously defended Japanese psychoanalysis against its

${ }^{1}$ Following the Japanese convention, the family name appears first. 
opponents and, in the post-war years, those supporters who favoured an increasing professionalisation (medicalisation) of psychoanalysis. He also defended Japanese psychoanalysis in the pages of the International Journal when it was criticised for what was seen by one western visitor as a practice compromised by incompatible cultural beliefs. Yet many accounts of these events treat Ohtsuki as a marginal figure (e.g. Marui, 1939; Kaketa, 1958; Taketomo, 1990; Okonogi, 1995). ${ }^{2}$ This may be because Japanese psychoanalysis tends to be written of as an emergent subdiscipline of psychiatry, although sensitive to culturally specific circles of influence. Yet-as we hope to show in this paper-this emergence was itself partly dependent upon the early co-operation of the lay analysts, among whom Ohtsuki was a significant representative, and without which psychoanalysis in Japan might not have arrived at its current accommodation of medical and non-medical practitioners.

\section{THE PATH TO FREUD}

Like many others, Ohtsuki was drawn to psychoanalysis because he saw it as a means of alleviating certain neurotic anxieties with which he had been burdened since childhood. He was born in 1891 into a comfortable family (his father was a district judge in Sumoto). He suffered from enuresis until the age of 8 , which, he says in his autobiography, might have been due to fear surrounding a concussion he incurred at the age of 4 while sleeping in a hammock (Ohtsuki, 1951). Coupled with a set of badly developed teeth resulting from poor dental treatment, he grew up very uncertain of himself. At school he was ill-natured and unfriendly, ${ }^{3}$ and, in spite of a promising beginning, performed badly academically. On leaving school, he enrolled in the Ueno School of Art but failed to buckle down to disciplined work and turned towards artistic life. He con- tracted typhoid fever in this period, and when his mother came from Kobe to nurse him, she herself succumbed fatally to the illness. Although no stranger to early bereavement (his older brother had died as an adolescent of tuberculosis), his mother's death shook Ohtsuki from his complacency. He left art school and decided to read for a degree in literature at Waseda University.

Waseda proved to be a congenial environment for study. He polished his skills in English and read widely. In seeking answers to his neurotic problems he was drawn to Ueno Yoichi's journal Shinri Kenkyu [Study of psychology] but, ironically, he took no interest in Freud at that time. He graduated in 1918, and with his improved knowledge of English, got a job in the Ministry of Railways writing and researching for travel guides. It was while he was there that he first encountered Yabe Yaekichi, the man who was to steer him towards analysis.

Yabe had studied experimental psychology in America and was conducting research at the Ministry into labour relations when he befriended Ohtsuki. Yabe's enthusiasm for psychoanalysis had blossomed as his interest in the experimental discipline had begun to wane. Under his informal tutelage (essentially casual conversations in the workplace), Ohtsuki's interest in the new discipline became 'tremendously enhanced'. Together with 'friends, teachers and critics', they formed a 'cultural research group', which led in 1928 to the formation of Japan's first psychoanalytic institute (Seishin Bunseki Kenkyukai). Along with Yabe and Ohtsuki, the other founding members were Tsushima Kanji and Hasegawa Seiya, the latter, a former professor at Waseda. They saw their first task as translating all of Freud's works at the time into Japanese (Ohtsuki, 1941).

By this time Ohtsuki had decided to embark upon a path of literary scholarship. He had resigned his position with the Railway Ministry in 1924, married, and had started writing

${ }^{2}$ Takeda (1990) is an exception.

${ }^{3}$ All citations from Japanese texts are translations by the author [SYHC]. 
essays and translations on the subject of art. He had already translated William Morris's Hopes and Fears for A rt from English, and philosopher Benedetto Croce's Aesthetics and the History of A esthetics from Italian. The latter he considered quite an accomplishment as the original makes liberal use of quotations in Greek, Latin, Dutch and Portuguese. By the time he decided to tackle Freud, his publisher (Shunyodo), on the basis of his proven track record as a translator, had agreed to take the project on. He had begun translating Freud while still employed at the Ministry, and set about it in earnest when he left. While his collaborators did some of the translations, Ohtsuki soon assumed the role of supervisor, and took on the lion's share of the work. Between 1930 and 1933, ten volumes appeared mostly translated by him from English and German editions (Yang \& Blowers, 1997).

To commemorate the occasion, Ohtsuki launched a psychoanalytic journal in 1933: Seishin Bunseki, which was also referred to in its English letterhead as the Tokyo Journal of Psychoanalysis'. That same year a play he had written, Yofu ['foster father'], was given a public performance in Tokyo's Asahi Shinbunsha Hall. It explored the moral and libidinal conflicts between a young woman and her foster father, a judge at the Supreme Court. A possible reworking of some of his own conflicts about his mother, it appeared to be a further demonstration of the confidence with which he had taken to this new-found discipline and made it his own, coming to see himself as its leading proponent in Japan. If this confidence sprang from his own narcissism, as Ohtsuki implies in his autobiography, it could also have been due to events surrounding the role played by the man who, along with others, would claim to be the pioneer of Japanese psychoanalysis: Marui Kiyoyasu.

\section{FACING THE ESTABLISH MENT}

Marui had been the first psychiatrist in Japan to teach Freud within the university establishment, in the department of psychiatry at Tohoku University in Sendai. Many in the Japanese medical profession gravitated to Germany for postgraduate training but in the advent of the Great War, Japan and Germany were cast on opposite sides. In 1918, Marui had gone to America and worked under Adolf Meyer, who had shown himself generally sympathetic to psychoanalysis although he was not a practitioner. Maruihad observed that psychiatrists in the US, applying American pragmatism to verifying the theoretical claims of the new science through its practical results, had incorporated it into their mainstream. When he returned to Japan, he began offering courses in psychoanalytic theory to medical students at Tohoku, where held the newly established chair of psychiatry. However, as Okonogi Keigo, a 'second-generation' analyst has noted, 'the mainstream psychiatric circle in Japan at the time was characterised by a German Kraepelinian trend. Marui's small isolated group was continuously subject to harsh criticism' (1995, p. 124). The establishment took the view that mental dysfunction required physical forms of treatment, which de facto disqualified psychoanalysis.

Psychoanalysis, via Marui, also had to endure criticism from another quarter-the psychiatrist Morita Masatake. Morita was developing a form of therapy at this time that resonated with his Zen Buddhist beliefs. The conventional psychiatric view had it that physical symptoms were a state of mental disease and that their removal by physical means was a sign that the disease had been halted. Depth psychology was predicated upon the idea that unconscious desire lay at the root of symptoms of anxiety and required probing and interpretation by an external agency - the analyst - to remove them. Morita's hypothesis was that desires rest upon a fundamental desire - the 'desire to live' [sei no yokubo]. The focus of his therapy was very much upon self-revelation and involved an integration of conflicting impulses, a learning to accept the circumstances of one's life, rather than an expunging 
of desires through the agency of another (Takeda, 1990).

Marui tolerated the opposing views of his colleagues and Morita without mounting a strong defence of his own position. Instead, he continued to teach and write general articles about theory. In 1927 he wrote to Freud requesting the rights to a Japanese translation of his complete works, which were granted (letter of Freud to Marui, 10 November 1927). ${ }^{4}$ But he did not keep Freud abreast of developments, nor perhaps realise that he had a competitor. Thus when Ohtsuki's colleague, Yabe Yaekichi, visited Freud in Berlin in 1930, two of the three existing Japanese translations of Freud's books had already been published by Ohtsuki's group.

Yabe had gone to Europe for three months under the sponsorship of the Railway Ministry to study psychoanalysis. He met Max Eitingon in March, then went to London and for the duration of his stay obtained a training analysis from Edward Glover, and instruction in theory from Ernest Jones. They were sufficiently impressed with him to waive the usual one-year training period. He stopped off in Berlin again on his way home, and Eitingon took him to Ernst Simmel's house, where he met Freud, and presented him with a translation of Beyond the Pleasure Principle (Yabe, 1931). Freud was likewise impressed and, thinking that Marui had lost interest in the translation project, granted Yabe the rights to future translations. He also gave him permission to have his institute formally admitted to the IPA and to be known as the IPA-Japan branch.

This action by Freud inadvertently proved catalytic in the split that was to emerge between the two groups, the doctors on the one hand and the lay analysts on the other.

When, in a letter of 13 December, Marui informed Freud he was sending him a copy of his translation of The Psychopathology of Everyday Life, Freud realised his own blunder and disclosed his recent actions in his reply (of 30 December 1930). Admitting fault, he asked Marui if he would help him out by coming to an arrangement with Yabe whereby the two groups combine to work on a single edition of translations. But it was too late. Marui, in his next letter (of 2 February 1931) informed Freud that his group had already published seven of the translations. He defended his group's clinic as being

the only one which devotes itself continually and systematically to the study of psychoanalysis ... [and] ... has been and is as yet at the head of the psychoanalytic movement in this country, and I am sure that people especially of the scientific class of this country acknowledge this fact.

Marui admitted that Yabe had written to him, apologising for not having consulted him about getting his own institute admitted to the IPA, and wanting to meet him. With this conciliatory gesture on Yabe's part, it seemed at this crucial stage that some kind of amalgamation of the groups was to develop. However, in the same letter, Marui made clear to Freud that he was seeking his own group's admission to the IPA and an analysis for himself from someone abroad. Freud then consulted Eitingon and between them they devised a solution that he relayed to Marui in next letter (of $15 \mathrm{M}$ arch 1931). Marui was to write to Eitingon to get his permission to form a branch at Sendai, 'and then establish a connection with Dr Yabe's group in a common organisation'. Marui's reply (of 7 April) confirmed he would attend to these requests. The latter suggestion clearly met with difficulties, of which Marui informed Freud in his next letter. ${ }^{5}$ Freud commiserated with him in his reply of 24 December.

In the meantime, Marui persevered with his teaching and started his own journal: Seishin Bunseki Soron, a bulletin of his Institute intended for internal distribution to students at Tohoku. When funding became available in

${ }^{4}$ Letters between Freud and his Japanese correspondents, Marui, Yabe, Ohtsuki and Kosawa, are held in the Freud Archives, Library of Congress, and were derestricted by the late Kurt Eissler.

${ }^{5}$ This letter is not in the Freud Archives, and has so far not been found. 
1933, he set off for Europe and in September paid a brief visit to Freud. During his onemonth stay in Vienna he was analysed by Federn, and delivered a lecture to the Psychoanalytic Society entitled 'The process of introjection in melancholia' (Marui, 1935). He then went to London in November at the invitation of Ernest Jones. His travelling diary at the time reveals more of his attempts to secure a position for his group in Japan. His visit to Freud, he believed, would grant him the authority to continue his psychoanalytic school and shield it from criticism, though the source of this feared criticism is not made clear. The entry of 18 September reads: 'I am pleased to have met Freud. Upon returning to Japan there will be no criticism accusing me of promoting a non-orthodox school of psychoanalysis'. He might have been alluding to comments from members of his own profession, including his student, Kosawa Heisaku, who had accused his mentor of promoting psychoanalytic theory but not its practice. $\mathrm{He}$ could also have been referring to opposition from allied disciplines (see above). It would appear that Marui felt unconfident about his current role, and that his visit to Freud would be seen as authorising him to practice. Freud's arranging this abbreviated one-month analysis in lieu of the normal period can be seen as a concession, possibly to make amends for prior events.

Further concessions were granted. Marui's diary entry for 12 November reveals that, as a result of two meetings with Jones that month, Jones agreed to Marui forming a Sendai branch of the IPA alongside Yabe's organisation, which would henceforth be known as the Tokyo branch of the IPA rather than the Japan branch. This effectively downgraded Yabe's institute to a regional rather than a national one. Finally, Marui's name was to appear on the front cover of the Internationale Z eitschrift für Psychoanalyse. Yabe was to be informed by Jones of these arrangements, which, according to Jones, (in a letter to Anna Freud, 19 January 1934) he subsequently seemed happy to accept.
If these events suggest that the initiatives of Yabe's lay analytical organisation had been a slight to Marui's esteem and confidence, no such role-conflict seemed to beset his ambitious student, Kosawa Heisaku. Kosawa had become interested in psychoanalysis through Marui's teachings but had grown dissatisfied with his mentor's seeming inability to analyse. Marui's learning of this new discipline had come through his studies in America, where Freud's ideas were disseminated in English translation. Kosawa had read Freud in German. According to Takeda Makoto, Kosawa's unhappiness with his mentor stemmed from Marui's technique. When analysing a patient, Marui would move from an identification of the symptoms to an interpretation, which he strongly encouraged the patient to accept. This left out the vitally important step of free association to the symptoms, which Marui was reluctant pursue. They had several arguments on these matters in the mid-1920s, with the result that Kosawa first approached Freud requesting an analysis from him (letter of 15 April 1925). Six years later, with a letter of recommendation from Marui, he went to Vienna for this purpose. He was eventually trained by Richard Sterba and supervised by Paul Federn, wrote an important paper outlining his own cultural view of the Oedipus complex, and returned in 1933 to Japan to open his own private practice in Tokyo (Kosawa, 1935). Marui went to Europe just after Kosawa returned (Blowers \& Yang, 1997).

\section{THE WAY AHEAD}

By the end of 1933, the hoped-for alliance the need for which Freud had impressed upon his Japanese disciples did not look promising. Marui led a small group of medical practitioners in Sendai; Yabe led a group of lay analysts in Tokyo, which also included some doctors. Having had a dispute with his mentor, Kosawa set up a private practice independently of both (Takeda, 1990) but remained a member of Marui's organisation, the Sendai Branch of the 
IPA. Yabe's group had invited the doctors to contribute to their journal, and Marui's and Kosawa's names appeared on the letterhead. Yabe's report to the IJP on activities for the year indicate that there was to be a second local society under Dr Marui, who, with his students and graduates had for a number of years past been actively working for the advancement of psychoanalysis in Japan, by publishing results of their studies and researches and public lectures. The following year his group voted unanimously to accept the second society (Sendai branch), and to rename their own the 'Tokyo Psycho-Analytical Society' (Yabe, 1934; Tsushima, 1935).

These acknowledgements do not appear to have been reciprocated. Later reports from Japan mention only the activities of Marui's group, which remained silent about their sister organisation.

It was Ohtsuki, a member of Yabe's group, who had not had the privilege of travelling to Europe and being analysed by Freud's associates, who took further steps to heal the breach. In the pages of his own journal he began defending Marui against his detractors. In the prefaces to the first two issues he condemned psychoanalytic critics, came to Marui's defence, and to the defence of lay analysis. Singling out the journal No [Brain], which had published an article by Marui alongside another by one of his critics, Ohtsuki quotes a passage, 'Recently there are a number of articles about psychoanalysis written by inexperienced people. Moreover, laymen have even undertaken some psychotherapy. Such a situation might cause misunderstandings in the appropriate development of psychoanalysis'. To this he responded,

I haven't seen any books written by inexperienced persons, but some translations likely exist. Besides, these translations have come under the supervision of MDs and university professors. Don't physicians, including the 'Brain' reporter who is most likely a physician, bring such a situation upon themselves? And as to the phrase, 'psychotherapies undertaken by laymen', the reporter reveals his ignorance. I would suggest he read carefully Freud's Outline of P sychoanalysis, On the His- tory of the PsychoanalyticM ovement and The Question of Lay Analysis. He will then realise that the physician is not entitled to monopolise the practice of psychoanalysis ...The presence of accurate and sensitive telepathy is the first qualification of an analyst. Without such a qualification, one would never be able to be an analyst even if one possessed ample medical knowledge (Ohtsuki, 1933a).

In the preface to the next issue, Ohtsuki responded to an article critical of psychoanalysis by the psychologist, Sato Koji, which had appeared in the journal Shinrigaku Kenkyu [Psychological research]. Identifying a common aim, both Professor Marui and myself maintain a tremendous interest in psychoanalysis and engage in its research enthusiastically', he addresses Marui directly, lamenting his lack of response to Sato himself: 'I have always respected your gentle personality but I don't think it a virtue to avoid debate for the truth. Freud is extremely blunt and extravagant in his arguments. Hopefully you will fight frankly for a new truth' (Ohtsuki, 1933b).

Marui seems not to have responded to these comments. Whatever his personal feelings, he was under pressure from his own institution for teaching psychoanalysis in the first place and might have preferred to avoid risking further censure by allying himself in any formal way with an essentially private group of interested practitioners. The two groups were to remain separate for another twenty years. Ohtsuki continued to edit his journal, which was never able to return a profit or even break even. Money he inherited from his father enabled it to continue up until 1941, when a paper shortage brought on by the outbreak of war forced it to cease publication.

In spite of these difficulties, the Tokyo group continued to meet regularly once a month right up the end of World War II. Throughout this period Ohtsuki's activities as an analyst increased. Although not initially confident in his ability to analyse and seemingly reluctant to do so, he nonetheless began treating patients as his knowledge of the subject grew from his extensive reading and translating. 'Because of the wishes of my patients, and for the purposes 
of research rather than treatment, I had to accept doing analysis', the doubts in so doing serving to 'nurture' him as an 'analyst and a scholar' (Ohtsuki, 1951).

There are several points to note here. From this source, and from an interview with Ohtsuki's widow in 1998, it would appear that Ohtsuki was largely self-trained. The records of the group sent to the International Journal (Yabe, 1934) indicate that Yabe trained many members and, as Ohtsuki was a founding member of the organisation, it is likely he also received instruction from Yabe. But it should also be borne in mind that Yabe and Kosawa had each had very limited training themselves, even as judged against the European standards of the day. Because of the limited time for them to be abroad, compromises had been made in Britain and Vienna in order to enable them to return home and begin training others. Yabe's analytic sessions with his patients in the first year of the Society averaged sixty-three in number. The records do not report how many sessions were required for training analyses. They do indicate that Yabe treated a number of children with character disorders, and others with anxiety, obsessional or borderline disorders. Analytic techniques varied among the early analysts. According to Marui's daughter, Sumiko, herself a trained analyst, her father conducted his sessions using a couch both at home and at the school. Ohtsuki Kimi reports her husband having treated his patients from his clinic and always with them facing each other, sitting in chairs, without making eye contact. The Society's meetings concentrated on reading the works of Freud, Jones, Ferenczi and Abraham. Ohtsuki studied these texts and presenting his ideas of analysis, especially as related to literature and drama in a subsidiary group of Yabe's devoted to this purpose. This helped to create a climate of exchange of ideas, helped by Ohstuki's skills as a writer and translator.

Ohtsuki took his role as an independent scholar seriously. In his autobiography he draws a distinction between scholars and professors, the latter being "well versed in the data and literature, but a scholar ... has the creative ability to systematise new ideas from the findings of the gathered and analysed data'. This leads him to a critique of the Japanese hierarchical system within univer sities:

Most founders of universities and departments maintain their creativity [but] their successors gain their position by kow-towing to their seniors' pleasure and playing the role of palace waiting-women. So in most cases their creativity is all dried up by the time they get assigned to their target positions, yet they are able to meet the requirements because the Japanese are all blind worshippers of position. The professors are all blind worshippers of foreign things; the general public blind worshippers of governmental schools. Position is revered (Ohtsuki, 1951, p. 51).

This is revealing of the very different situations in which Ohtsuki and members of his group were placed with respect to the doctors. Most of Marui's group could afford to maintain an interest in psychoanalysis without a deep commitment since they were funded within the government's education al and social system (schools and clinics), which, on the whole, was not sympathetic to this form of treatment. Ohtsuki, on the other hand, was not an employee of any organisation but a selffunded scholar, as were many of his group (although a few of them were doctors in private practice). His interest in psychoanalysis, a foreign and largely unknown mode of thinking in Japan, coupled with his autonomy as a scholar, free from institutional pressure, made for the stronger commitment, and came to shape his views of what qualities an analyst should possess. These were first and foremost a natural ability or gift [tensai sei] followed by honesty and a humanitarian concern for and sensitivity to others. Lastly, there was intelligence. While conceding that academics and physicians were invested with the latter, their qualifications did not necessarily run to the first two. According to his archivist, Ohtsuki took the view that the possession of natural gifts and a genuine honesty in communication were an obstacle to the preservation of the power structures in universities. For this reason 'one should get out of 
that system to develop one's creativity' (Yamauchi Kazuyoshi, 2000, personal communication). $\mathrm{He}$ and his group continued to be active right up the conflict of the Second World War, translating psychoanalytic works, publishing original articles, seeing patients and holding meetings.

\section{THE AFTERMATH OF WAR}

Yabe died in 1945. Like many inhabitants of Tokyo, Ohtsuki retreated to the countryside to escape the air-raids, and was granted a small parcel of land to become a farmer. The gen erally meagre and frugal circumstances of his life fitted him better to the ravages of the last few war-torn months of that year than did those of many university professors, some of whom, he notes in his autobiography, were forced to take lowlier positions, such as small restaurateurs. A few committed suicide. $\mathrm{He}$ settled down in $\mathrm{Nasu}$ to a relatively peaceful life. After the war, the local medical authorities were encouraged to adopt the models of the occupying forces of America. Psychoanalysis was then a dominant psychiatric model that provided a different focus from the previously popular German somatic one. The Sendai branch under Marui reported to the International Journal in 1949 that it had survived the war and had thirteen active members. Marui had moved on to the vicechancellorship of Hirosaki University. By 1954 the membership had expanded to thirtyseven, including eleven honorary members, all of whom were doctors. Marui died in 1953 and his former student Kosawa Heisaku assumed the Presidency. Kosawa had been running a private practice in Tokyo along with a small group of psychoanalytically inclined people since the war and was to play a pivotal role in the upgrading of the Sendai branch into becoming the national society member of the IPA.

Ohtsuki meanwhile relaunched his journal in 1952. He had remained an active proponent of psychoanalysis and opened his own clinic,
The Tokyo Institute for Psychoanalysis. He wrote several original works, some of whose titles (How to Make Your Home Happy [1949], Analytical Advice to Patients on the Couch [1938], How to Foster Self-confidence [1966]), suggest he had his eye on providing a wider appeal. At the same time he was also engaged in more 'serious' works ranging from An Introduction to Psychoanalysis (1948) and A Study of Good and Evil (1947) to A Dictionary of Psychoanalysis (1972). The journal by this time boasted a number of overseas associate editors on its cover, Ohtsuki having continued to make overtures to the international psychoanalytic community to support his venture. However, he remained apart from the activities of the Sendai branch, which was now growing larger in the aftermath of the occupation and was dominated by medical practitioners.

All the more surprising then, that it again fell to him to defend Japanese psychoanalysis when it came under the critical scrutiny of a foreigner.

\section{TROU BLE FROM ABROAD}

In 1954, the American psychoanalyst James Clark Moloney, who visited Japan twice in the nineteen forties, published a book called Understanding the Japanese Mind. This was an extension of a paper he published in the International Journal in 1953 to which Ohtsuki took strong exception (Moloney, 1953, 1955; Ohtsuki, 1955). It was Moloney's contention that psychoanalysis as practised in Japan was not psychoanalysis at all but a syncretic variant that had accommodated itself to certain intractable features of the Japanese collectivist culture. $\mathrm{H}$ is argument was that, because of the rigidly hierarchical nature of Japanese society with its emphasis on the need for people to live harmoniously with others, a therapy that stresses individual freedom and independence is unworkable. He drew his support from a literal reading of a book entitled Kokutai no Hongi [Cardinal Principles of the National 
Entity of Japan-H all, 1949] which, as Ohtsuki pointed out in his response,

was compiled by official writers, under the supervision of the wartime Department of Education, with the military-political purpose of controlling public opinion. It is definitely not a book that should be regarded as a fair representation of Japanese thinking in general (Ohtsuki, 1955, p. 207).

Moloney had assumed it was and, in the closing paragraphs of his book, he reminds the reader that adapting Freudian psychoanalysis to its prerequisites 'is a super abstraction that extends beyond the tangible limits of reality' (1954, p. 218). He also casts aspersions on the work of the three analysts who had received some training abroad by claiming that, in spite of the duration of their training being not particularly short by the standards of Freud's day, 'as a group [they] have not been sufficiently analysed or sufficiently trained to practice effective psychoanalysis themselves' (p. 135).

Ostensibly well-intentioned (to correct former racial stereotypes of the Japanese as being 'inscrutable', 'mysterious' and 'unpredictable'), Moloney's tract can be read today as a thinly disguised attempt to carry out a psychosocial analysis of a culture labouring under an occupation force intent on introducing American-style principles of democracy, in order to predict the likelihood of it either returning to pre-war national militarism or sliding into communism. There are chapters on Japan's history and on child-rearing, and on the means for coming to know the Japanese mind. But the thrust of the book is an enquiry into Japanese psychoanalysis. To gather materials, Moloney wrote to, and obviously got help from, Ohtsuki, as well as Kosawa and other psychiatrists, some of whom were members of the Sendai branch of the IPA. In drawing upon several articles culled from Ohtsuki's pre-war journal, he used knowledge gained about psychoanalytic enquiries into Japanese minds to affirm his view of Japanese culture. Then, from this vantage, he attempted to undermine the credibility of Japanese analysts' claims to be practising psychoanalysis as that was under- stood in the West. Considering how helpful several local practitioners had been, it is all the more surprising that none of the 'established members', i.e. those with medical credentials, felt called upon to respond to the criticisms of his book. Several could easily read English texts (encouraged under the occupation as the emphasis shifted to more English language learning). Only Ohtsuki, by now something of an ignored figure within the new circle, felt compelled to respond.

Moloney had been the first outsider to raise the question of the effectiveness of psychoanalysis as practised in Japan. Freud had on several occasions in his communications with his Japanese correspondents lamented that he could not read the translations and journals that they sent him, and asked that they provide summaries in English so that he could check their understanding against his own. He had expressed the wish to visit all his 'dear friends in Japan' and would liked to have done so were it not for his ill health (letter to Ohtsuki, 25 June 1935). Moloney had done what Freud had only wished: gone to Japan and made enquiries (mainly through letters), secured materials and commissioned his own translations. His conclusions were nonetheless harsh and unwarranted.

Ohtsuki's reply was succinct. Moloney's sources were of dubious validity and he had seriously misunderstood the nature of Japan society in comparison to his own. It is possible to be both collectivistic (Moloney used the term nationalistic) and yet act as an individual at the same time. All societies, including American society, are stratified and ordered. Individual identity in Japan is not swallowed up in nationalistic identity.

The basis of this debate has been subsequently developed by later researchers from both within and outside the culture who, like Ohtsuki, have concluded that analysis in Japan is possible, although the terms of the analytic relationship are different (see for example, Doi, 1973; Kawada, 1977; De Vos, 1980; K itayama, 1987; Roland, 1988). As elsewhere, other forms of psychoanalytic psychotherapy have emerged 
alongside orthodox psychoanalysis without risking nihilistic condemnation. Moloney's case was overstated, even though by then there were indications that Japanese psychoanalysis was beginning to take on the mantle of cultural adaptation (Doi, 1993). It is noteworthy that it was Ohtsuki who first challenged him, and independently of any institutional support, though he had a strong supporter in Richard Sterba, who encouraged him to respond to Moloney in the International Journal (letter of Sterba to Ohtsuki, 25 May 1954). He clearly felt he was the head of the movement, even if this was not unanimously acknowledged. In replying to Moloney, he also revealed something of the differences that were beginning to emerge in the practice of psychoanalysis between himself and Kosawa Heisaku, whom he now considered a rival.

\section{EXILE}

Kosawa had started a psychoanalytic research institute in Tokyo in 1949 whose membership was made up of analysts-in-training, and a group interested in psychoanalytic studies (Taked a, 1990). Prior to the war he had been a lone figure in private practice, though he had become a member of the Sendai Psychoanalytic Society under his former mentor, Marui Kiyoyasu. Several university students from Kyushu, Keio and Niigata universities were now becoming interested in psychoanalysis and gravitated towards him as one of the two surviving Japanese analysts who had received an analysis abroad from Freud's colleagues. Because he was able to attract students from some of the national universities who recognised his analytic experience, Kosawa's status as an aspiring post-war leader of the fledging psychoanalytic movement was becoming assured. It might then have been reasonable then that his group should seek some form of international recognition.
From correspondence lodged in the archives of the IPA, and examined by Taketomo Yasuhiko, ${ }^{6}$ it appears that Kosawa wrote to Marui informing him of his intention to seek affiliation for his society to the IPA, while aware that the Sendai society of which he and Marui were members was already recognised from pre-war years as an IPA member (letter of Marui to Bartemeier and Hartmann-IPA Presidents18 January 1952). Marui hoped Bartemeier would not grant Kosawa such a request. $\mathrm{He}$ had earlier signalled his intention of having his Sendai organisation become the national society of Japan, first to Jones (in a letter of 4 August 1949) and subsequently to Bartemeier, with whom he entered into a correspondence between 1950 and 1952 .

When Marui Kiyoyasu died in 1953, Kosawa assumed the presidency of the Sendai branch. He was then briefly head of both the Sendai Psychoanalytic Society and the Tokyo Institute and amalgamated them to create the Japan Psychoanalytic Association [Nihon Seishin-bunseki Gakkai] on the 30 May 1955, recognised by the IPA. According to Taketomo, the Association announced its international identity as the Japan Psychoanalytic Society, which would be limited to specifically qualified medical psychoanalysts. At the same time the Association itself would be open to non-medical professionals, which 'opened the way for the merging of the third current-[that which] had been led by Yabe and Ohtsuki' (Taketomo, N.D., p. 8).

However, no amalgamation with Ohtsuki's group took place. It is not clear why, although Okonogi has suggested that it might have been because Ohtsuki was not perceived to practise psychoanalytically (2000, personal communication). But, as we have argued here, this appears unlikely. Ohtsuki was a founding member of one of the two pre-war psychoanalytic groups, both of which were initially recognised by the IPA. His close association to Yabe, who took on the role of training others, his

\footnotetext{
${ }^{6}$ Reported in his unpublished work-in-progress, 'Cultural adaptation to psychoanalysis: Japan 1912-1953' from which we cite with his permission. This will be a much enlarged version of his earlier work (Taketomo, 1990).
} 
opening of his own clinic and seeing patients, coupled with the publication of some of his own cases in the Japanese journal of psychoanalysis which he founded (Ohtsuki, 1957c,d) would have given him considerable visibility and prominence amongst the immediate postwar generation of analysts. In any event, many people were admitted to the larger umbrella organisation who were not analysts but who professed an interest in psychoanalysis. Ohtsuki more than met this criterion with his dual roles as editor and translator of one of the first two sets of Freud's complete works into Japanese. Indeed, one of his own group members from the early nineteen thirties, Sakurai Fumiko, who also came from a humanities background, contributed to his journal (Sakurai, 1957) and attended some of the meetings of Kosawa's post war group, was admitted to the JPA (Doi, 2000, personal communication; Owaki, 1965).

In a previous paper we mentioned that Ohtsuki was invited to join but declined, as he was only offered the Vice-Presidency and felt it a slight to his esteem (Blowers \& Yang, 1997). In an editorial since unearthed in Ohtsuki's own journal, it would appear he was not invited (Ohtsuki, 1957b). His widow revealed in a recent interview that, at the time of the formation of the JPA, Kosawa had wanted Ohtsuki's Seishin Bunseki to become its official journal. A more likely reason, as Taketomo suggests, was Ohtsuki's uncompromising critiques of the medical profession and academia. According to Okonogi Eiko, who at one time worked as a secretary to Kosawa, it might have been because of their incompatibility [uma ga awanai] that Ohtsuki was kept out.

Had he been admitted there would have been a problem, given his pre-war status, of what position he might have assumed. The American outlook dominated Japanese psychiatry, from the mid-fifties on. Given that country's rejection of the lay analytic enter- prise, against Freud's defence of it (Freud, 1927), it is perhaps not surprising that there might have been some kind of opposition in Japan to a literati leading the newly established group. Kosawa, having visited Vienna and undergone a three-month analysis with one of Freud's associates (Sterba), was likely accorded the same esteem as the founder of the Sendai branch, and in the eyes of the psychiatrists at the time, was thus one of the only two men able to initiate training analyses. This made him the obvious choice for leading the inauguration of the Japan Society as a fully-fledged IPA national member.

Ohtsuki was nonetheless bitter. Kosawa had contributed to his journal yet failed to acknowledge him as a forerunner. ${ }^{7} \mathrm{He}$ continued in his editorials to be critical of his rival. In a scathing editorial in Seishin Bunseki (1957b), he accused Kosawa of lacking common sense and of being indiscreet and manipulative of his patients, whom Ohtsuki came to treat subsequently. He was also critical of Kosawa's group hailing their own mentor, Marui, as the 'father of Japanese psychoanalysis', a title which Ohtsuki felt should have been bestowed on himself (Ohtsuki, 1957a,b). A further reason for his bitterness might have been because an agreement between him and the Freud estate over publication rights of a new Japanese translation of Freud's works went sour. According to Taketomo's unpublished manuscript, Anna Freud originally gave him permission to proceed in 1950 (letter of Anna Freud to Secretary of the IPA, Grete Bibring, $7 \mathrm{March}$, in Takemoto, N.D.). However, Freud's sons apparently received a better offer from another publisher and cancelled his contract the following year. This rival publisher (Nippon Kyobun-sha) also produced works of Seicho no Ie [House of growth], a religious sect founded in 1925 by Taniguchi Masaharu-whose doctrine bore a similarity to Christian Science and which, according to Kosawa, in an approving letter to

${ }^{7}$ Acknowledging Kosawa's contribution to the fact-gathering for his book, Moloney recounted that Kosawa was donating thirty copies of the Japanese psychoanalytic journal, Seishin Bunseki, to the Menninger Clinic. He failed to mention that this was the journal founded by Ohtsuki. 
J. Rother of Imago publishing (of 19 July 1951, in Takemoto, N.D.), 'also uses theories of psychoanalysis to explain his doctrine'.

Ohtsuki continued his cordial relations with many overseas analysts, including Jones, to whom he wrote seeking permission for translations of some of his works, while suspecting him of having, if inadvertently, passed on to Moloney remarks about Ohtsuki attributed to a 'rival Japanese colleague'-Kosawa (letter of Ohtsuki to Jones, 2 April 1955). He entertained the Dutch analyst, Joost Meerloo, based in New York, while on a visit to Tokyo in 1957 and also corresponded with Erich Fromm, with whom he shared an interest in the relationship between psychoanalysis and Buddhism (Ohtsuki, 1956).

He continued to write prolifically for the remainder of his life (he died in 1977) and kept up the journal that he had founded back in the early thirties, which eventually ran for thirtyfive volumes. It ceased publication upon his death. His output had been prodigious: he had written 63 books, 931 papers (of which 256 were in English) and he had translated 41 books from other languages, not including his translations of Freud (Fukuda, 1978).

His later writings appeared to mix psychoanalytic ideas with Buddhist philosophy. In this he was not so different from other analysts, including Kosawa who, during his period in Vienna, had adapted Freud's theory of the myth of Oedipus to the Buddhist one of Ajase in order to bring psychoanalytic understanding to bear on the central feature in Japanese society of the mutual dependency of motherson relations (Kosawa, 1935; Ohtsuki, 1956).

Where Kosawa had impressed a cultural variant on Freud's proclaimed universal oedipal theme, Ohtsuki focused on Freud's theory of instincts and sought to substitute it with his own 'Life analysis' [seimei bunseki gaku]. By so doing, he attempted to extend the debate on Freud's metapsychology of the duality of the life and death instincts. From a Buddhist standpoint, Freud's conception of the death instinct as an overarching principle, which accounts for things returning to a primordial inorganic state, bore a theoretical resemblance to the Nirvana principle, which Yabe Yaekichi had pointed out to Freud when he visited him in 1930 and presented him with a Japanese translation of Beyond the Pleasure Principle (Yabe, 1931). Ohtsuki, in a common line of reasoning, drew a distinction between Asian and western thinking. The former was predicated upon an 'unconscious synthetic principle' while the latter was essentially antithetical in nature. What this comes down to is that western minds find more congenial a form of investigation of the constituent parts of the psyche using methods of interrogation based upon psychoanalytic principles. Asian minds require some adaptation of its methods and aims. A therapeutic goal of Ohtsuki's analysis was then defined by the oxymoron "harmonious conflicts'-the acceptance of a divided nature rather than the eradication of one impulse in favour of another. This was becau se he saw the tendency to preserve and destroy-Freud's erotic and destructive drives - as being part of the life cycle, which would eventually lead to stabilisation of experience. In his thinking, his ideas come close to those developed from within Morita therapy, which to this day, in Japan and elsewhere, continues to draw many adherents to its claims.

In spite of his earlier defence of psychoanalytic orthodoxy against the criticisms of Moloney, Ohtsuki's own 'Life analysis' can be seen as an example of a cultural adaptation of Freudian concepts.

While winning the admiration of many overseas analysts to whom he regularly sent the journal (only the editorials were in English), he was largely ignored in the psychoanalytic circle that had now established formal links to the IPA. By remaining outside the Japan Psychoanalytic Association, Ohtsuki's influence on post war developments in the field extended only to the workings of his own group. They continued to meet regularly, hold annual conferences and publish the journal. As its editor, the journal was his main mouthpiece. With its English-language editorials it became the only viable serial transmitting information and 
knowledge about Japanese culture from a psychoanalytic standpoint to the west.

He continued to curry favour abroad and remained interested in developments on the international scene. Many internationally renowned analysts had their articles appearing in translation in his journal. Moloney (1955) cites, among others, Wittels, Jekels, Jung, Glover, Brill, Anna Freud, Reik, Hitschman, Eissler, Piaget, Abraham, Rank and Alexander. Ohtsuki's considerable language skills made him the foremost translator of psychoanalytic articles. This was a skill he acquired early and it was to benefit the early development of psychoanalysis in Japan. Coming from a humanities background, his initial collaboration with the psychologist, Yabe, who had been the first Japanese to be given a training analysis, gave him the edge over the medically trained Marui in terms of translation work, seminars and training. It could be argued that this more than anything else prompted the doctor, Marui, to seek recognition from Freud for his own group's activities, which eventually led to the doctors becoming allied to the IPA. However, by the time this occurred, in hindsight, it had less to do with their enthusiasm for depth psychology than for their need to adhere to the fashions of American psychiatry being imposed upon them by the occupational forces in the immediate aftermath of the Second World War. Depth psychology became a trend amongst many in the developing field of psychiatry. For the lay analysts however it was the raison d'être of the emerging post-war professions of counselling and clinical psychology. By not being tied to a medical model they were freer to develop their own theories by making use of their rich and diversified cultural experiences in much the same way as their forerunner Ohtsuki had done.

\section{POSTSCR IPT}

Although this paper has concentrated on Ohtsuki's largely neglected contribution s to the development of psychoanalytic ideas in Japan, and his ultimate exclusion from the Japan Psychoanalytic Association, it would be misleading to conclude that Japan's analytic doctors were hostile to lay analysis, or that the formation of the Society merely followed the international strictures of the day in attempting to keep lay analysts out. Unlike the situation involving America's national psychoanalytic society's entry to the IPA, some of the Japanese groups comprising doctors, non-medical specialists and other interested parties were keen to amalgamate. The formation of the twin arrangements of the organisation (JPS/JPA) enabled many lay analysts to join the larger group, and the doctors sympathetic to psychoanalysis worked alongside other professional colleagues in various aspects of the theory and practice of psychoanalysis. There were some pockets of bitterness, especially as a few lay analysts who had already been trained were denied entry to the JPS, but on the whole, the arrangement proved harmonious to many who came from a variety of backgrounds and training and who were admitted to the umbrella organisation. It is this larger group to whom all the members had looked for intellectual situation. This contrasts, for example, with the situation in the US, where lay analysts were kept out but where only in recent years has there been a gradual acceptance of them into the IPA, and this only after a hard-fought struggle (Wallerstein, 1998).

There continues to be a question of what defines lay analysis and who might be suitably eligible candidates. The IPA currently admits to membership societies that comprise "psychologists, clinical social workers and academics from ten humanities' (Freedman \& Sanville, 1999). Ohtsuki, as man of letters, would probably have qualified under this category, but his contribution, we suggest, should be judged against the conditions prevailing in Japan at the time, where he moved in largely uncharted psychoanalytic territory.

Acknowledgements. We would like to thank Ohtsuki Kimi, widow of the late Ohtsuki Kenji, and her son Ohtsuki Takeji (now deceased), for 
their hospitality and for supplying many source documents. Also, Marui Sumiko for access to the diaries of her late father Marui Kiyoyasu, Yamauchi Kazuyoshi, Ohtsuki's archivist, Keith Davies of the Freud Museum, Fred Bauman of the Library of Congress, Drs Osamu Kitayama and Okonogi Keigo, and Professors Paul Roazen, Doi Takeo and Taketomo Yasuhiko.

\section{TRANSLATIONS OF SUMMAR Y}

L'auteur souligne l'importance du rôle qu'a joué Ohtsuki Kenji dans la formation de la Société Psychanalytique Japonaise. Contrairement aux autres pionniers de la psychanalyse au Japon, Ohtsuki ne rencontra jamais Freud et n'alla jamais à l'étranger. Il était diplômé en littérature et s'était enseigné en autodidacte les principes de psychanalyse. Il organisa la traduction des oeuvres complètes de Freud, créa un institut de formation psychanalytique et publia un journal contenant des éditoriaux de langue anglaise. Ceux-ci devinrent le moyen principal par lequel les analystes étrangers vinrent à connaître et comprendre la scène psychanalytique japonaise. Un nombre de groupe rivaux se mirent ensemble pour former l'Association Psychanalytique Japonaise au milieu des années cinquante, excluant le groupe de Ohtsuki malgré sa proéminence d'avant-guerre. L'auteur reconsidère le rôle d'Ohtsuki à la lumière de ses nombreux articles, de son autobiographie, et des nouvelles informations découvertes dans des entretiens avec des analystes contemporains ainsi qu'avec la veuve de Ohtsuki et son fils. Ils décrivent sa lutte pour la psychanalyse profane, et sa critique de la médicalisation de la discipline, ainsi que sa critique des vues venant de l'étranger et doutant de l'efficacité de la thérapie psychanalytique pour la culture japonaise, ainsi que ses efforts visant à modifier certains des principes de base de la psychanalyse pour s'accorder à ses vues personnelles dans ses derniers travaux.

Die Autoren stellen die bedeutende Rolle dar, die Ohtsuki Kenji in der Bildung der Japanischen Psychoanalytischen Gesellschaft gespielt hat. Anders als die anderen Pioniere der Psychoanalyse in Japan, ging Ohtsuki niemals ins Ausland und begegnete niemals Freud. Er studierte Literatur und brachte sich selbst die Grundlagen der Psychoanalyse bei. Er organisierte die Übersetzung der gesamten Werke Freuds, gründete ein psychoanalytisches Ausbildungsinstitut und begann eine Zeitschrift, die englischsprachige Leitartikel brachte. Diese wurde das Hauptmittel, mit dem ausländische Analytiker die japanische psychoanalytische Szene kennen und verstehen lernten. Einige rivalisierende Gruppen bildeten Mitte der Fünfziger Jahre zusammen die Japanische Psychoanalytische Vereinigung unter Ausschluss von Ohtsukis Gruppe trotz deren Vorrangstellung vor dem Kriege. Die Autoren überdenken Ohtsukis Rolle im Lichte seiner vielen Artikel, seiner Autobiographie und neuer Information, die in Interviews mit heutigen Analytikern, seiner Witwe und seinem Sohn zu Tage trat. Diese beschreiben sein Engagement für die Laienanalyse, seine Kritik an der Medikalisierung der Disziplin und an der aus dem Ausland kommenden Ansicht, die die Eignung der japanischen Gesellschaft für psychoanalytische Therapie infrage stellte, sowie seine Bemühungen, einige der grundlegenden psychoanalytischen Lehrsätze zu verändern, um sie seinen eigenen Sichtweisen in seinem späten Werk anzupassen.

Los autores subrayan el papel fundamental desempeñado por Ôhtsuki Kenji en la formación de la Sociedad Psicoanalítica Japonesa. A diferencia de otros pioneros del Psicoanálisis japonés, Ôhtsuki nunca viajó al extranjero ni conoció a Freud. Era un Licenciado en Literatura, auto-didacta en cuanto a los fundamentos del Psicoanálisis. Impulsó la traducción de las obras completas de Freud, organizó un Instituto de formación psicoanalítica y fundó una Revista que incluía editoriales en inglés. Todas éstas fueron vías fundamentales por medio de las cuales los analistas extranjeros llegaron a conocer el Psicoanálisis japonés. En la década de los años 50, se fusionaron algunos grupos rivales para formar la Asociación Psicoanalítica Japonesa y excluyeron al grupo de Ôhtsuki, a pesar de la importancia que éste había tenido antes de la guerra. Los autores re-consideran el papel de Ôhtsuki a la luz de sus muchos artículos, de su auto-biografía y de información nueva, no incluida en entrevistas hechas a psicoanalistas actuales, a su viuda y a su hijo. Describen su defensa de los psicoanalistas no médicos, sus críticas a la medicalización de la disciplina y a algunas posturas surgidas en el extranjero que cuestionaron el que la cultura japonesa fuera adecuada para el Psicoanálisis; e, igualmente, los esfuerzos que hizo en su último trabajo, por modificar algunos de los principios básicos del Psicoanálisis y hacerlos concordar con sus propios puntos de vista.

\section{REFERENCES}

BLOWERS, G. H. \& YANG, S. H. (1997). Freud's deshi: the coming of psychoanalysis to Japan. $J$. Hist. Behav. Sci., 33: 115-26.
De Vos, G. (1980). Afterword. In The Quiet Therapies, ed. D. K. Reynolds. Honolulu: Univ. of Hawaii Press. 
DoI, T. (1973). The Anatomy of Dependence. Tokyo: Kodansha International.

(1993). Psychoanalysis in a cross-cultural context: a Japanese view. Unpublished MS read at the 1993 Congress of the IPA.

Freedman, N. \& SAN Ville, J. (1999). The Confederation of Independent Psychoanalytic Societies in the US: a brief historical perspective. IPA Newsletter, 8 (2).

FREUd, S. (1901). The Psychopathology of Everyday Life. S.E. 6.

(1920). Beyond the Pleasure Principle. S.E. 18. (1927). Postscript to The Question of Lay Analysis. S.E. 20.

FUKUDA, K. (1978). Postscript: the natural powers of healing. In Ningenwa dokomade shokia [Normality: to what extent?] by K. Ohtsuki. Tokyo: Ikubunsha.

H ALL, R. K. (ED.) (1949). Cardinal Principles of the National Entity of Japan [Kokutai No Hongi], trans. J. O. Gauntlett. Cambridge, MA: Harvard Univ. Press.

KaketA, K. (1958). Psychoanalysis in Japan. Psychologia, 1: 247-52.

KAWADA, A. (1977). Psychoanalyse und psychotherapie in Japan. Psyche, 31: 272-85.

KitAYAMA, O. (1987). Metaphorisation-making terms. Int. J. Psychoanal., 68: 499-509.

Kosawa, H. (1935). Zaiakuishikino nishu [Two types of guilt consciousness-Oedipus and Ajaze] Seishin Bunseki, March-April.

Moloney, J. C. (1953). Understanding the paradox of Japanese psychoanalysis. Int. J. Psychoanal., 34: 291-303.

(1954). Understanding the Japanese Mind. New York: The Philosophical Library.

Moloney, J. C. (1955). Reply to Ohtsuki. Int. J. Psychoanal., 35: 207-8.

MARUI, K. (1935). The process of introjection in melancholia. Int. J. Psychoanal., 16: 49-58.

(1939). Die Psychoanalyse in Japan. Gelbe Post, 1: 9.

Ohtsuki, K. (1933a). Preface. Seishin Bunseki, Vol. 1., No. 1.

(1933b). Preface. Seishin Bunseki, Vol. 1, No. 2. (1938). Jubunsekisha no kokoro. [Analytical advice to patients on the couch]. Tokyo: Tokyo Institute for Psychoanalysis.

(1941). History of psychoanalysis in Japan. Seishin Bunseki, 9: 2-3.
(1947). Zen aku no kenkyu. [A study of good and evil]. Seishinbunseki sousho [Bulletin of psychoanalysis], 16. Nasu: Tokyo Institute for Psychoanalysis.

- (1948). Seishibunsekgaku gairon. [Introduction to psychoanalysis]. Tokyo: Iwasaki-shoten. - (1951). Seishinbunsekiteki Jiden. [A psychoanalytical autobiography]. Kanreki Kinencho. [Commemoration of 60th birthday].

(1955). The misunderstanding of Japanese psychoanalysis: a protest against the views expressed by Dr. J. C. Moloney. Int. J. Psychoanal., 35: 205-7.

(1956). Freud and Buddhism. Seishin Bunseki, 14 (1).

(1957a). Mythology is useless in the psychoanalytic field: the real Professor Marui Kiyoyasu. Seishin Bunseki, 15: 1-5.

- (1957b). Some critical observation s of the soassumed academical group of psychoanalysts. Seishin Bunseki, 15: 1-2.

(1957c). A case of a manly narcissistic male with some obsessional symptoms. Seishin Bunseki, 15: 17-25.

(1957d). A case of obsessional phobia for compulsive onanism. Seishin Bunseki, 15: 26-9.

(1966). Jishin wo yashinauhou. [How to foster self-confidence]. Tokyo: Tokyo Institute for Psychoanalysis.

(1972). Seishinbunsekigak u jiten. [A diction ary of psychoanalysis]. Tokyo: Ikubunsha.

(1978). Ningenwa dokomade shokia. [N ormality: to what extent?]. Tokyo: Ikubunsha.

__ \& TSUKASAKI, S. (1949). Katei no koufuku. [How to make your home happy]. Tokyo: Shirasagisha.

OKONOGI, K. (1995). 'Japan.' In Psychoanalysis International: A Guide to Psychoanalysis Throughout the World, Vol. 2, ed P. Kutter. Stuttgart-Bad Cannstatt: Frommann-Holzboorg, pp. 123-41.

Owaki, N. (1965). Preface. In Seishin Bunseki Numon Koza. [Lectures introducing Psychoanalysis]. By F. Sakurai. Japan Clinical Hypnosis Institute.

Roland, A. (1988). In Search of Self in India and Japan. Princeton, NJ: Princeton Univ. Press.

SAKURAI, F. (1957). A case (male) of anxiety hysteria. Seishin Bunseki, 15: 12-16.

Takeda, M. (1990). Seishin Bunseki to Bukkyo. [Psychoanalysis and Buddhism]. Tokyo: Shinchosa. 
Tакетомо, Y. (1990). Cultural adaptation to psychoanalysis in Japan, 1912-1953. Social Research, 57: 951-91.

- (N.D.). Cultural adaptation to psychoanalysis: Japan 1912-53. Unpublished MS.

Tsushima, K. (1935). Tokyo Psycho-Analytical Society: report for the year 1934. Int. J. Psychoanal., 16: 261-2.

W ALLER STEIN, R. S. (1998). Lay A nalysis: Inside the Controversy. Hillsdale, NJ: Analytic Press.
YABE, Y. (1931). Furoido Sensei Kaikenshi [A meeting with Professor Freud]. In Furoido Seishin Bunsekigaku Zenshu. [Freud's Collected Works on Psychoanalysis. Trans. Alan Fraser. Vol. 5., Appendix: 1-19.]

(1934). Japan: report on psychoanalytic activities in the year 1933. Int. J. Psychoanal., 15: 377-9. YANG, S. H. \& Blowers, G. H. (1997). The early Japanese translations of Sigmund Freud's works: an annotated list. Univ. of Hong Kong Social Science Research Centre Occasional Paper No. 20.

Geoffrey Blowers and Serena Yang Hsueh Chi Copyright @ Institute of Psychoanalysis, London, 2001 Dr Blowers

Department of Psychology

University of Hong Kong

Bonham Road

Hong Kong

(Initial version received 11/10/99)

(First revised version received 3/7/00)

(Final revised version received 5/9/00) 